\title{
PROFIL KETERAMPILAN PROSES SAINS SISWA DALAM PEMBELAJARAN IPA KELAS VIII DI SMP NEGERI 8 TANJUNGPINANG
}

\author{
Jumania $^{1 *}$, Azza Nuzullah Putri ${ }^{2}$, Bony Irawan ${ }^{3}$ \\ 1, 2, ${ }^{3}$ Program Studi Pendidikan Biologi, FKIP, Universitas Maritim Raja Ali Haji
}

Pengiriman: 14 Juli 2019; Diterima: 2 Oktober 2019; Publikasi: Oktober 2019

\begin{abstract}
This research aims to describe science process skills in science learning at the eight grade of SMP Negeri 8 Tanjungpinang. This research uses descriptive quantitative approach. The sample of this research were students from VIII A, VIII C, and VIII E grade of SMP Negeri 8 Tanjungpinang. Data in this research was gained from observation sheets instrument and test science process skills. The result of analysis showed science process skills of students VIII grade was good. Based on average result of science process skills from observation sheets is $66 \%$ in good category, and the result of science process skills from test is $68 \%$ in good category. When viewed from the test result the aspect of submitting hypotheses with a percentage is $54 \%$ enough category of the sample used class. Teachers suggested to develop more science process skills in the learning, both in terms of test, discussion, and experiment.
\end{abstract}

Keywords: Science Process Skills, Science Learning, Profile

ABSTRAK. Penelitian ini bertujuan untuk mendeskripsikan keterampilan proses sains siswa dalam pembelajaran IPA kelas VIII di SMP Negeri 8 Tanjungpinang. Penelitian ini menggunakan metode penelitian deskriptif. Sampel yang digunakan kelas VIII A, VIII C, dan VIII E di SMP Negeri 8 Tanjungpinang. Data dikumpulkan melalui lembar observasi dan tes keterampilan proses sains. Hasil analisis data menunjukkan bahwa keterampilan proses sains siswa kelas VIII dapat dikategorikan baik. Berdasarkan hasil rata-rata keterampilan proses sains dari lembar observasi terukur sebesar $66 \%$ dengan kategori baik. Begitu juga dengan hasil tes keterampilan proses sains menunjukkan rata-rata persentase 68\% dengan kategori baik. Jika dilihat dari hasil tes aspek mengajukan hipotesis dapat dikategorikan cukup dengan persentase 54\% dari kelas sampel yang digunakan. Disarankan kepada guru lebih dapat mengembangkan keterampilan proses sains siswa dalam pembelajaran, baik itu dari segi tes, diskusi serta percobaan.

Kata kunci: Keterampilan Proses Sains, Pembelajaran IPA, Profil

*Penulis korespondensi

Alamat surel: jumania_syahrun@yahoo.co.id 
PENDAHULUAN

Pendidikan merupakan proses yang dilakukan secara sadar dan terencana untuk mengembangkan berbagai potensi peserta didik. Pendidikan yang diharapkan oleh bangsa dan negara adalah pendidikan karakter (Andriani, 2018: 1). Pendidikan karakter merupakan suatu upaya untuk membentuk generasi agar berakhlak mulia. Usaha pendidikan berkarakter ini diperlukan untuk menumbuhkan dan meningkatkan mutu karakter generasi sekarang dan masa depan. Pendidikan tidak hanya ingin menghasilkan manusia yang cerdas dalam akademi, tetapi pendidikan juga mengharapkan manusia memiliki akhlak mulia setelah memperoleh pendidikannya.

Proses belajar harus diarahkan untuk mengantarkan peserta didik agar mampu mengatasi setiap tantangan dan rintangan dalam kehidupan yang cepat berubah, melalui sejumlah kompetensi yang harus dimiliki (Jufri, 2013: 43). Dengan begitu proses belajar menekankan peserta didik agar mencari dan menemukan informasi yang lebih dari sekedar didapati dari pendidikannya di sekolah. Pembelajaran yang terjadi harus berpusat kepada peserta didik secara langsung (student centered). Pembelajaran dikatakan berpusat kepada peserta didik ialah peserta didiklah yang berperan aktif dalam proses belajar. Peserta didik yang aktif akan menumbuhkan kemampuan berpikir, bekerja dan bersikap ilmiah serta mengkomunikasikannya sebagai aspek penting kecakapan hidup (Fatonah \& Prasetyo, 2014: 21).

Karakteristik sains yang mempelajari fenomena-fenomena alam sekitar, tubuh manusia, hewan, dan lainnya memerlukan adanya keterampilan-keterampilan sains agar materi dapat diserap dengan baik, Berdasarkan hasil wawancara dengan guru IPA yang didapat oleh peneliti di SMP Negeri 8 Tanjungpinang, yaitu guru sudah menerapkan pembelajaran yang sesuai dengan Kurikulum 2013. Guru sudah menumbuhkan keterampilan proses sains kepada siswa dengan menggunakan metode pembelajaran, seperti diskusi kelompok dan praktikum atau percobaan. Sebelum kegiatan praktikum dilakukan, guru sudah memberikan panduan praktikum untuk memudahkan siswa dalam melakukan kegiatan praktikum. Oleh karena itu, peneliti tertarik untuk mengetahui profil keterampilan proses sains siswa kelas VIII di SMP Negeri 8 Tanjungpinang pada pembelajaran IPA.

\section{METODE PENELITIAN}

Penelitian ini dilakukan dengan menggunakan metode deskriptif. Penelitian deskriptif merupakan penelitian yang menggambarkan dan menginterpretasikan kondisi yang ada, proses yang sedang berlangsung, dan akibat yang sedang terjadi. Setelah data didapatkan, peneliti melakukan analisis data dengan mendeskripsikan menggunakan kata-kata. Sampel yang digunakan dalam penelitian ini sebanyak 91 siswa, yang terdiri dari kelas VIII A, VIII C, dan VIII E. Siswa melakukan kegiatan pembelajaran dengan metode praktikum yang diajar oleh guru IPA di kelas. Penentuan subjek penelitian dengan teknik simple random sampling.

Instrumen penelitian yang digunakan terdiri dari lembar lembar observasi dan tes keterampilan proses sains. Lembar observasi untuk melihat keterampilan proses sains siswa secara langsung dalam praktikum terhadap materi gerak pada tumbuhan putri malu. Aspek keterampilan proses sains yang digunakan dalam penelitian ini terdapat 7 aspek, yaitu melakukan observasi, mengelompokkan, mengajukan hipotesis, merencanakan percobaan, menginterpretasi data, menarik kesimpulan, dan mengkomunikasikan hasil (Modifikasi dari Samatowa, 2016: 101-102 \& Rustaman, 2003: 4). Tes keterampilan proses sains terdiri dari 6 soal uraian yang berisi aspek keterampilan proses sains mengenai materi gerak pada tumbuhan putri malu.

Instrumen divalidasi berdasarkan validitas konstruk oleh validator terlebih dahulu. Siswa dibentuk dalam berkelompok dengan beranggota 5-6 orang setiap kelompoknya. Lembar observasi dilakukan oleh dua pengamat, yaitu peneliti dan guru IPA SMP Negeri 8 Tanjungpinang. Tes sebagai data pendukung dari instrumen lembar observasi. Penskoran instrumen dilakukan dengan penskoran 4-0, yaitu siswa yang memunculkan semua (tiga) indikator maka memperoleh skor 4. Jika hanya memunculkan dua indikator maka siswa memperoleh skor 3. Jika hanya satu dari tiga indikator yang muncul maka siswa memperoleh skor 1. Sedangkan siswa yang tidak 
memunculkan indikator dari aspek-aspek keterampilan proses sains maka siswa tidak memperoleh skor (skor 0).

Skor lembar observasi dihitung berdasarkan indikator apa saja yang muncul disetiap aspek keterampilan proses sains selama praktikum. Hasil tes didapatkan melalui setiap jawaban siswa dari yang benar dan lengkap sampai dengan siswa yang tidak memberikan jawaban. Data berupa skor hasil lembar observasi dan tes keterampilan proses sains dari setiap sampel diolah dengan menggunakan analisis deskriptif dan interpretasinya berdasarkan persentase dari penskoran yang telah didapat saat pembelajaran dan tes.

\section{HASIL DAN PEMBAHASAN}

Keterampilan proses sains yang diukur dalam penelitian ini ada tujuh aspek, yaitu keterampilan melakukan observasi, mengelompokkan (klasifikasi), mengajukan hipotesis, merencanakan percobaan, menginterpretasi data, menarik kesimpulan, dan mengkomunikasikan hasil (Samatowa, 2016: 101-102 \& Rustaman, 2003: 4). Berdasarkan tabel 1 hasil lembar observasi pada kategori baik. Aspek tertinggi terdapat pada aspek melakukan observasi, sedangkan kategori terendah pada aspek mengkomunikasikan hasil. Berdasarkan tabel 2 hasil tes pada kategori baik. Tes keterampilan proses sains yang diukur dalam penelitian ini menggunakan enam aspek. Aspek yang tidak digunakan dalam mengukur keterampilan proses sains pada tes, yakni aspek melakukan observasi. Aspek tertinggi terdapat pada aspek klasifikasi, sedangkan aspek terendah pada aspek mengajukan hipotesis.

Tabel 1. Hasil Penilaian Lembar Observasi Keterampilan Proses Sains

\begin{tabular}{clccccc}
\hline \multirow{2}{*}{ No } & \multirow{2}{*}{ Aspek KPS } & \multicolumn{3}{c}{ Kelas VIII } & \multirow{2}{*}{ Rata-rata (\%) } & \multirow{2}{*}{ Kategori } \\
\cline { 3 - 6 } & & $\mathbf{A ~ ( \% )}$ & $\mathbf{C}(\boldsymbol{\%})$ & $\mathbf{E ~ ( \% )}$ & & Baik \\
\hline 1 & Observasi & 79 & 75 & 68 & 74 & Baik \\
\hline 2 & Mengelompokkan & 71 & 57 & 64 & 64 & Baik \\
\hline 3 & Hipotesis & 71 & 61 & 54 & 62 & Baik \\
\hline 4 & Merencanakan percobaan & 75 & 57 & 100 & 77 & Baik \\
\hline 5 & Interpretasi data & 57 & 54 & 75 & 62 & Baik \\
\hline 6 & Menarik kesimpulan & 75 & 54 & 57 & 62 & Baik \\
\hline 7 & Mengkomunikasikan & 71 & 54 & 57 & 61 & Baik \\
\hline & Rata-rata & $\mathbf{7 1}$ & $\mathbf{5 9}$ & $\mathbf{6 8}$ & $\mathbf{6 6}$ & Baik \\
\hline
\end{tabular}

Tabel 2. Hasil Tes Keterampilan Proses Sains

\begin{tabular}{clccccc}
\hline \multirow{2}{*}{ No } & \multirow{2}{*}{ Aspek KPS } & \multicolumn{3}{c}{ Kelas VIII } & \multirow{2}{*}{ Rata-rata (\%) } & \multirow{2}{*}{ Kategori } \\
\cline { 3 - 5 } & & $\mathbf{A ~ ( \% )}$ & $\mathbf{C ~ ( \% )}$ & $\mathbf{E ~ ( \% )}$ & 73 & Baik \\
\hline 1 & Klasifikasi & 75 & 78 & 68 & 54 & Cukup \\
\hline 2 & Hipotesis & 50 & 48 & 65 & 72 & Baik \\
\hline 3 & Merencanakan percobaan & 68 & 73 & 76 & 72 & Baik \\
\hline 4 & Menarik kesimpulan & 68 & 73 & 75 & 63 & Baik \\
\hline 5 & Interpretasi data & 65 & 70 & 54 & 74 & Baik \\
\hline 6 & Mengkomunikasikan & 78 & 80 & 65 & $\mathbf{6 8}$ & Baik \\
\hline & Rata-rata & $\mathbf{6 7}$ & $\mathbf{7 0}$ & $\mathbf{6 7}$ & Baik &
\end{tabular}

Adapun tabel perbandingan rata-rata keterampilan proses sains (KPS) hasil dari lembar observasi dan tes sebagai berikut. 
Tabel 3. Perbandingan Rata-rata KPS Hasil Lembar Observasi dan Tes

\begin{tabular}{ccccc}
\hline Kelas & Rata-rata LO & Kategori & Rata-rata Tes & Kategori \\
\hline VIII A & $71 \%$ & Baik & $67 \%$ & Baik \\
\hline VIII C & $59 \%$ & Cukup & $70 \%$ & Baik \\
\hline VIII E & $68 \%$ & Baik & $67 \%$ & Baik \\
\hline Rata-rata & $\mathbf{6 6 \%}$ & Baik & $\mathbf{6 8 \%}$ & Baik \\
\hline
\end{tabular}

Berdasarkan tabel perbandingan di atas, dapat dilihat bahwa hanya di kelas VIII C yang memiliki angka rata-rata paling kecil dari kelas VIII A dan VIII E dengan rata-rata $59 \%$. Berbeda pula dengan rata-rata hasil tes, bahwa angka yang paling besar terdapat di kelas VIII C dengan rata-rata $70 \%$. Secara keseluruhan dari

hasil lembar observasi dan hasil tes menunjukkan keterampilan proses sains kelas VIII di SMP Negeri 8 Tanjungpinang dapat dikategorikan baik.

Hasil penelitian aspek melakukan observasi (mengamati) dilakukan dengan lembar observasi saja. Tes tidak dipergunakan karena peneliti mengalami kesulitan dalam memvalidasi tes pada aspek ini. Aspek melakukan observasi kelas VIII di SMP Negeri 8 Tanjungpinang diketahui berdasarkan hasil penelitian pada kategori baik. Hal ini dikarenakan siswa dapat berinteraksi secara langsung dengan objek percobaan. Walaupun masih ada beberapa siswa yang mengabaikan indikator mengamati suatu objek secara detail menggunakan kelima indera, yang merupakan salah satu indikator dari aspek melakukan observasi. Menurut (Samatowa, 2016: 94) keterampilan mengamati siswa akan baik tidak hanya dengan menggunakan indera, tetapi juga dapat mengamati dengan menggunakan alat-alat praktikum.

Aspek mengelompokkan (klasifikasi) kelas VIII di SMP Negeri 8 Tanjungpinang diketahui berdasarkan hasil penelitian lembar observasi pada rata-rata $74 \%$ berada dalam rentang 68\% - 79\% dengan kategori baik. Siswa dikatakan dapat mengelompokkan dilihat dari hasil laporan praktikum pada lembar kerjanya. Sementara itu, berdasarkan hasil tes siswa memiliki rata-rata $73 \%$ berada dalam rentang $68 \%$ - 78\% dengan kategori baik. Siswa sudah bisa memahami maksud dari soal mengenai aspek mengelompokkan. Hal ini sejalan dengan pernyataan (Kurniawati, 2015: 67) bahwa keterampilan mengelompokkan peserta didik dapat dikategorikan baik, jika sebagian besar peserta didik dapat menguasai keterampilan mengelompokkan.

Aspek mengajukan hipotesis berdasarkan hasil lembar observasi dapat dikategorikan baik, karena pada saat pembelajaran berlangsung penelitian dilakukan melalui lembar observasi. Siswa belajar secara berkelompok yang membuat hasil lembar observasi tidak begitu spesifik, karena dengan berkelompok siswa yang satu dengan siswa lainnya (dalam satu kelompok) akan saling melengkapi. Jika ada siswa yang memiliki kekurangan akan ditutupi oleh siswa lainnya.

Tes mengajukan hipotesis dikategorikan cukup, karena sebagian besar siswa tidak dapat menjawab soal tersebut dengan benar. Kebanyakan siswa mengira soal tersebut menanyakan alat dan bahan praktikum gerak pada tumbuhan putri malu. Oleh karena itu, tes aspek mengajukan hipotesis harus disesuaikan lagi. Agar tidak terjadi penafsiran ganda pada soal tersebut. Menurut (Riati, 2015: 2) hipotesis dapat dirumuskan dari masalah-masalah yang telah diidentifikasi dan dapat dirumuskan dalam bentuk pertanyaan (jika dan maka).

Hasil penelitian aspek merencanakan percobaan menunjukkan bahwa dari hasil lembar observasi pada rentang $57 \%$ - 100\% dengan rata-rata $77 \%$. Hal ini dikarenakan siswa sudah bisa melakukan dengan baik dari indikator menentukan alat dan bahan percobaan, menentukan apa yang (diamati, diukur dan ditulis), serta menentukan tujuan dan langlah kerja. Sesuai dengan pendapat (Indriastuti., dkk, 2013: 128) siswa pandai menyiapkan alat dan bahan praktikum yang dibutuhkan untuk kegiatan praktikum sehingga aspek merencanakan percobaan tercapai dengan baik. Begitu pula pada hasil tes, siswa sudah memahami maksud dari soal tersebut dengan benar. Hasil tes terlihat pada kategori baik dalam rentang 68\% - 76\% dengan rata-rata $72 \%$.

Aspek menginterpretasi data memiliki hasil penelitian dengan kategori baik dari hasil lembar 
observasi dan tes. Menurut (Rustaman, 2003: 4) untuk memperoleh hasil interpretasi data yang baik, dalam membuat instrumen harus menyajikan sejumlah data untuk memperlihatkan pola. Berdasarkan hasil lembar observasi, aspek menginterpretasi data berada dalam rentang $54 \%-75 \%$ dengan rata-rata $62 \%$. Siswa sudah bisa melakukan interpretasi data dengan baik, hanya saja jika dilihat dari hasil laporan praktikum sebagian besar siswa belum memunculkan indikator menghubungkan setiap hasil pengamatan yang diperoleh. Berbeda dari hasil tes, aspek menginterpretasi data berada dalam rentang $54 \%-70 \%$ dengan rata-rata $63 \%$.

Hasil penelitian dari lembar observasi dan tes aspek menarik kesimpulan dapat dikategorikan baik. Berdasarkan hasil lembar observasi, aspek menarik kesimpulan berada dalam rentang $54 \%-75 \%$ dengan rata-rata $62 \%$. Hal ini dapat dikatakan siswa sudah bisa menarik kesimpulan dengan benar. Hanya saja masih banyak siswa yang belum memunculkan indikator menemukan pola atau kecenderungan hasil praktikum.

Siswa memiliki hasil yang baik, jika dilihat dari hasil tes dibandingkan dengan penyampaian (presentasi) di depan kelas. Oleh karena itu, hasil tes aspek menarik kesimpulan berada dalam rentang $68 \%-75 \%$ dengan rata-rata $72 \%$. Menurut Nurhasanah (2016: 13) siswa dapat dikatakan memiliki keterampilan menarik kesimpulan, jika siswa mampu menggeneralisasikan dari suatu rangkaian hasil kegiatan percobaan dan tes tertulis.

Aspek terakhir dalam penelitian keterampilan proses sains adalah mengkomunikasikan hasil. Berdasarkan hasil lembar observasi dan tes, aspek mengkomunikasikan hasil dapat dikategorikan baik. Hasil lembar observasi menunjukkan sampel berada dalam rentang $54 \%-71 \%$ dengan rata-rata $61 \%$. Hanya saja saat presentasi di depan kelas, indikator menyampaikan informasi dalam bentuk model, gambar, grafik, dan diagram tabel tidak semua kelompok menampilkannya. Kebanyakan kelompok menyampaikan informasi hasil percobaan hanya dengan membacakan hasil diskusi kelompoknya saja.

Aspek mengkomunikasikan hasil dapat dilihat dari hasil percobaan atau yang sering disebut lembar kerja siswa (LKS) dan tes. Berdasarkan hasil tes aspek mengkomunikasikan hasil berada dalam rentang $65 \%-80 \%$ dengan rata-rata $74 \%$. Sebagian besar siswa sudah bisa menjawab maksud dari indikator soal mengenai aspek mengkomunikasikan hasil. Menurut (Samatowa, 2016: 96) bentuk komunikasi yang baik adalah yang dapat dipahami dan dimengerti oleh penerima informasi, baik itu secara tertulis maupun lisan.

Berdasarkan tabel 3 perbandingan rata-rata nilai persentase keterampilan proses sains dari hasil lembar observasi dan tes berbeda. Secara keseluruhan keterampilan proses sains siswa kelas VIII SMP Negeri 8 Tanjungpinang berada pada kategori baik. Penyebab utamanya dikarenakan berbeda guru yang mengajar saat pembelajaran berlangsung di kelas VIII C. Sedangkan di kelas VIII A dan VIII E pembelajaran dilakukan oleh guru yang sama. Selain itu, nilai persentase antara lembar observasi dan tes keterampilan proses sains berbeda dikarenakan adanya dua pengamat di dalam satu kelas. Pengamat melakukan observasi dengan membagikan objek yang akan diteliti masing-masing tiga kelompok per kelas.

\section{SIMPULAN}

Berdasarkan rata-rata keterampilan proses sains dari lembar observasi terukur sebesar $66 \%$ dengan kategori baik. Begitu juga dengan hasil tes keterampilan proses sains menunjukkan rata-rata persentase $68 \%$ dengan kategori baik.

\section{SARAN}

Pada penelitian ini, peneliti memiliki beberapa saran sebagai berikut.

1. Guru, sebaiknya lebih mengembangkan keterampilan proses sains siswa dalam pembelajaran. Guru juga sebaiknya lebih memperhatikan siswa secara menyeluruh, agar tidak ada siswa yang tidak mengikuti pembelajaran yang sedang berlangsung dengan seksama.

2. Siswa, hendaknya sudah memahami konsep atau materi yang akan dipraktikumkan. Agar lebih dapat memperlancar proses pembelajaran.

3. Peneliti lainnya, hendaknya dapat mengembangkan indikator-indikator disetiap aspek keterampilan proses sains. Tidak hanya terpaku dengan indikator- 
FKIP Universitas Maritim Raja Ali Haji

ISSN 2503-0752 e-ISSN: 2579-4132

indikator yang sudah dilakukan oleh peneliti sebelumnya.

\section{DAFTAR PUSTAKA}

Andriani, Ria. 2018. Korelasi Sikap Ilmiah Siswa Dengan Hasil Belajar IPA Kelas VIII Pada Materi Gerak Pada Makhluk Hidup di MTsN Pangian. Skripsi FTIK, Institut Agama Islam Negeri, Batu Sangkar.

Fatonah, Siti., \& Prasetyo, Zuhdan, K. 2014. Pembelajaran Sains. Yogyakarta: Ombak.

Indriastuti, dkk. 2013. Kesiapan Laboratorium Biologi dalam Menunjang Kegiatan Praktikum SMA Negeri di Kabupaten Brebes. Unnes Journal of Biology Education(2).

Jufri, Wahab. 2013. Belajar dan Pembelajaran SAINS. Cetak ke-I, Bandung: Pustaka Reka Cipta.

Kurniawati, Astri. 2015. Analisis Keterampilan Proses Sains Peserta Didik Kelas XI Semester II MAN Tempel Tahun Ajaran 2012/2013 Pada Pembelajaran Kimia Dengan Model Learning Cycle $5 e$. Skripsi JPK. FMIPA. UNY.

Nurhasanah. 2016. Penggunaan Tes Keterampilan Proses Sains (KPS) Siswa dalam Pembelajaran Konsep Kalor dengan Model Inkuiri Terbimbing. Skripsi FITK, UIN Syarif Hidayatullah Jakarta.

Riati, Mimis. 2015. Keterampilan Proses dalam Pembelajaran IPA di SD. http://www.academia.edu/11483235/KE TERAMPILAN_PROSES_DAN_PEND
EKATAN_SAINTIFIK_IPA_DI_SD.

Diakses tanggal 30 November 2018.

Rustaman, N. Y., dkk. 2003. Strategi Belajar Mengajar Biologi. Common Textbook JICA IMSTEP. Bandung: FPMTP A UPI.

Samatowa, Usman. 2016. Pembelajaran IPA di Sekolah Dasar. Cetakan ke-III, Jakarta Barat: Indeks.

Zubaidah, Siti., dkk. 2014. Buku Guru Ilmu Pengetahuan Alam SMP/MTs Kelas VIII. Pusat Kurikulum dan Perbukuan, Balitbang, Kemendikbud. 